\title{
A CRITIQUE OF ECONOMIC AND SOCIOLOGICAL THEORIES OF SOCIAL CONTROL
}

\author{
ROBERT C. ELLICKSON*
}

\begin{abstract}
$\mathrm{H}$
ow is it that people manage to live side by side without incessant "warre of every man against every man"?" Thomas Hobbes, who won fame for posing this question, concluded that the legal system-the rules and might of Leviathan-is the wellspring of social order. Most law professors implicitly propagate this Hobbesian view, perhaps because it lends significance to what they teach. Law-and-economics scholars have been particularly prone to assert the centrality of legal doctrine. There is an opposing intellectual tradition, however, that emphasizes that social order can emerge without law. Its core theorists have been empirical sociologists and anthropologists who study stateless societies. Within the legal academy the law professors associated with the law-and-society movement have been the prime skeptics of the importance of law. ${ }^{2}$

A field study that I recently conducted in Shasta County, California, provides an empirical perspective on the sources of social order. The

* Robert E. Paradise Professor of Natural Resources Law, Stanford Law School. I thank Richard Epstein, Lawrence Friedman, Ronald Gilson, A. Mitchell Polinsky, Stanton Wheeler, and participants at a workshop of the University of Toronto Faculty of Law for helpful suggestions. I especially thank Donald Black and Richard Lempert, who have independently striven to educate me in the sociology of law. Cheryl Davey and Thomas Hagler provided able research assistance. Financial support was received from the Stanford Legal Research Fund, which was made possible by a bequest from the estate of Ira S. Lillick and by gifts from Roderick E. Hills and Carla A. Hills and other friends of the Stanford Law School. (This article is part of a forthcoming book to be published by the Harvard University Press.)

1 Thomas Hobbes, Leviathan 98 (Oxford Univ. Press ed. 1909).

2 When using the term "law-and-society movement," I refer to scholars who are prone to contribute to and read the Law \& Society Review and to be active in the Law and Society Association. Many of them have roots in the disciplines of sociology, anthropology, political science, and history. Although most regard themselves as social scientists, they tend to be relatively humanistic, and many reject the rational-actor model of human behavior that lawand-economics scholars typically apply.
\end{abstract}

[Journal of Legal Studies, vol. XVI (January 1987)]

(C) 1987 by The University of Chicago. All rights reserved. 0047-2530/87/1601-0007\$01.50 
study investigated how rural residents resolve disputes arising over damage done by stray livestock. ${ }^{3}$ Much of the Shasta County evidence casts doubt on the Hobbesian view. In areas of Shasta County that are legally designated as "closed range," a victim of cattle trespass is legally entitled to recover damages from the livestock owner on a strict-liability basis. In "open-range" areas, by contrast, a victim of trespass across an unfenced boundary has no rights to legal redress. I found that the rural residents of Shasta County (and even the insurance adjusters who settle minor trespass claims) pay almost no heed to these legal rules. The operative rule in both open- and closed-range areas is an informal norm that the owner of livestock is responsible for the conduct of his animals. Shasta County residents rely mainly on self-help to enforce this norm.

In other domains of Shasta County life, however, the legal system provides the supreme rules. Claimants who have suffered property damage arising out of highway collisions between vehicles and livestock routinely file claims with liability insurers; when they have suffered personal injuries, they hire attorneys who file complaints in court. Ranchers who would never sue neighbors whose cattle trespassed would not hesitate to sue to protect water rights.

When I sought to place my findings from Shasta County in theoretical perspective, I found current theories of social control inadequate. This article seeks to demonstrate those inadequacies. In Section I, I identify as expansively as possible the components of the overall system of social control. These components include not only the legal system and informal norms but also instruments such as self-control, contracts, and nongovernmental organizations. Sections II-III invoke portions of the typology of Section I to criticize, respectively, the current theories of scholars in the law-and-economics and the law-and-society movements. (Because these critiques are relatively freestanding, a hurried and narrowly focused reader may be able to skip Section I.) The central point of Section II is that law-and-economics has exaggerated the role that the legal system plays in the overall system of social control. The central point of Section III is that law-and-society scholars have been remiss in developing theories that explain the content of rules. To suggest the gains that might be forthcoming if current theoretical gaps were filled, Section IV concludes with a hypothesis of wealth-maximizing norms. This hypothesis offers an explanation for why Shasta County norms, for example, both hold a

\footnotetext{
${ }^{3}$ A first installment of my findings is Robert C. Ellickson, Of Coase and Cattle: Dispute Resolution among Neighbors in Shasta County, 38 Stan. L. Rev. 623 (1986). My forthcoming book will more fully describe what I found.
} 
rancher accountable for his livestock and forbid a victim of cattle trespass from using the legal system.

\section{The System of Social Control}

A system of social control consists of rules of normatively appropriate human behavior. These rules are enforced through sanctions, whose administration is governed by other rules. ${ }^{4}$ To help describe alternative systems of social control, I distinguish between two types of sanctions, five controllers that administer sanctions and make rules, and five types of rules. My taxonomy will honor, when possible, the current scholarly vocabulary of social control. ${ }^{5}$

\section{A. Rewards and Punishments: The Sanctions Suitable to a Tripartite Normative Classification of Human Actions ${ }^{6}$}

Systems of social control typically employ both rewards and punishments - both carrots and sticks - to influence behavior. ${ }^{7}$ In administering these positive and negative sanctions, enforcers usually apply rules that divide the universe of human behavior into three categories: (1) good behavior that is to be rewarded, (2) bad behavior that is to be punished, and (3) ordinary behavior that warrants no response. Figure 1, which illustrates a tripartite classification system of this sort, employs the standard sociological adjectives "prosocial" and "antisocial" to describe outof-the-ordinary behavior. Economists would use "goods" and, when

\footnotetext{
${ }^{4}$ See text at notes 28-34 infra.

5 Any taxonomy of course threatens too sharply to cleave scattered phenomena that are not readily distinguished. On the perils of taxonomic approaches, see John Griffiths, The Division of Labor in Social Control, in 1 Toward a General Theory of Social Control 37 (Donald Black ed. 1984). But language invariably overgeneralizes. That visible light lies in a continuum from infrared to ultraviolet does not render the word "green" useless.

6 This section draws on ideas developed in Robert C. Ellickson, Alternatives to Zoning: Covenants, Nuisance Rules, and Fines as Land Use Controls, 40 U. Chi. L. Rev. 681, 72833 (1973). See also Donald Wittman, Liability for Harm or Restitution for Benefit? $13 \mathrm{~J}$. Legal Stud. 57 (1984).

${ }^{7}$ Rewards are goods, services, or obligations to which a person would assign a positive monetary value; punishments are goods, services, or obligations that a person would pay to be rid of. The distinction between punishments and rewards is well developed in behavioral psychology, where the two are sometimes referred to as positive and negative reinforcement, respectively. Since Durkheim, sociologists have distinguished between penal and compensatory (restitutive) modes of social control. These are two different forms of punishment. What sociologists sometimes call therapeutic social control 1 would identify as a reward system; the person who seeks help from others is rewarded for recognizing and trying to remedy his plight. On these and other sociological distinctions, see Donald Black, The Behavior of Law 4-6 (1976).
} 


\begin{tabular}{ll}
$\frac{\text { prosocial behavior }}{\text { ordinary behavior }}$ & a reward-triggering rule \\
\hline antisocial behavior & a punishment-triggering rule
\end{tabular}

FIGURE 1.-A tripartite classification of human behavior

pressed, "bads" to describe these two extremes. People who act antisocially are "deviants"'; people who act prosocially are "surpassers."

If the members of a social group were to wish to move behavior in a prosocial direction (upward in Figure 1), they conceivably could employ fewer than three normative classifications. For example, they could use a bifurcated system that dropped the ordinary-behavior category and that thus looked like the one in Figure $2 .^{8}$ Or they could employ only punishments (rewards) as sanctions and have a bifurcated system consisting of two categories, that is, ordinary and punished (rewarded) behavior.

Finally, one could imagine a social control system that placed all behavior in the same normative category and that thus eliminated the need for the establishment of substantive rules whose role was to trigger changes in sanctions. For example, a society could establish an unachievable standard of perfect behavior for human conduct and levy penalties on all behavior, with the penalties presumably growing in magnitude as the deviation from perfection increased.

These unitary and bifurcated systems seem alien because in most social contexts people employ tripartite normative systems that make use of rewards, punishments, and no sanctions at all. Baseball fans, for example, cheer a shortstop's fielding gems, boo his errors, and sit on their hands when he handles a routine ground ball. Or suppose an automobile were to stall, block traffic in one of the two northbound lanes of a congested limited-access highway, and create a mile of backed-up vehicles. Most drivers would probably perceive that another motorist who stopped to direct traffic would be acting prosocially, that motorists who quietly waited out the jam would be acting ordinarily, and that motorists who leaned on their horns while they waited would be acting antisocially.

As both examples indicate, the rules used to evaluate human behavior tend to be set so that the "ordinary" category encompasses most conduct

\footnotetext{
${ }^{8}$ Homans has defined norms (I think incorrectly) as rules of this character: "[A] norm is a statement specifying how one or more persons are expected to behave in given circumstances, when reward may be expected to follow conformity to the norm and punishment, deviance from it." George C. Homans, Social Behavior: Its Elementary Forms 97 (rev. ed. 1974).
} 
prosocial behavior

reward/punishment switch-point rule

antisocial behavior

Figure 2.-A bifurcated classification of human behavior

that occurs. This approach has the advantage of reducing the costs of administering sanctions: that which is most common requires no response. ${ }^{9}$

Because behavior that ordinarily occurs typically warrants no punishment, the word "norm" is ordinarily used in English in a potentially ambiguous way. "Norm" denotes both behavior that is normal and behavior that people should mimic to avoid being punished. These two usages are potentially conflicting because almost everyone laments some features of the status quo. That the word "norm" has been able to maintain these two usages is a linguistic clue that ordinary behavior is only rarely regarded as antisocial behavior.

\section{B. Sources of Rules and Sanctions: The Controllers Involved in Creating Social Order}

It is useful to distinguish between five controllers that may be sources of both rules of behavior and sanctions that back up those rules. There are first-party, second-party, and third-party controllers. An actor who imposes rules and sanctions on himself is exercising first-party control. ${ }^{10} \mathrm{~A}$ promisee-enforced executory contract is a system of second-party control over the contingencies that the contract explicitly covers; the person

9 The prevalence of tripartite systems is a clue that rulemakers are attuned to an overarching goal of minimizing costs, including administrative costs. Compare text at note 114 infra (hypothesis of wealth-maximizing norms). A century ago some courts held that ordinary behavior could not be tortious. See, for example, Titus v. Bradford, B. \& K.R.R., 136 Pa. 618, 626, 20 A. $517,518(1890)$ : " $[\mathrm{H}]$ owever strongly they may be convinced that there is a better or less dangerous way, no jury can be permitted to say that the usual and ordinary way, commonly adopted by those in the same business, is a negligent way for which liability shall be imposed." Today, compliance with custom is rarely an ironclad defense in a tort case. See, for example, The T. J. Hooper, 60 F.2d 737 (2d Cir. 1932) (businesses may lag in adopting safety devices).

${ }^{10}$ The more a self-control system arises from a person's own reason, as opposed to external socialization, the more accurate the label "first party." Whatever the origin of selfenforced moral systems, there is broad agreement that they can be an important source of social control. See, for example, Thomas C. Schelling, Micromotives and Macrobehavior 128 (1978); Michael Taylor, Anarchy and Cooperation 7-8 (1976); John W. Thibaut \& Harold H. Kelley, The Social Psychology of Groups 134-35 (1959); and James Q. Wilson, The Rediscovery of Character: Private Virtue and Public Policy, Pub. Interest, 1985. No. 81, at 3. Llewellyn thought that education, not law, was responsible for achieving the basic order in a society. See Karl Llewellyn, The Bramble Bush 107-18 (1951). He thus emphasized the combined roles of the self-control and the informal control systems. 
acted on administers rewards and punishments depending on whether the promisor adheres to the promised course of behavior. Third-party control differs from second-party control in that the rules are ones to which the actor never explicitly agreed, and the sanctions are administered by persons not involved in the initial interaction. Third-party controllers can be either nonhierarchically organized social forces; organizations (nongovernmental hierarchies that make and enforce rules); or governments (state hierarchies).

\section{Controllers' Rules: Of Law and Norms}

I refer to the rules that emanate from first-party controllers as personal ethics, those from second-party controllers as contracts, those from social forces as norms, those from organizations as organization rules, and those from governments as law. ${ }^{11}$ (Although I will have something to say about all of these, I will emphasize law and norms, the rules whose interaction I studied in Shasta County.)

Max Weber, surely one of the most impressive theorists of social control, applied a somewhat different taxonomy. Weber defined law as the rules enforced by bureaucrats who specialize in social control activity. ${ }^{12}$ Weber's approach strains ordinary language because it is insensitive to the identity of the controller who has made or who is enforcing the rules. For example, employees of debt-collection agencies are specialized bureaucratic enforcers, but one ordinarily thinks of them as enforcers of contracts, not of laws. Similarly, if the Catholic church were to use specialized bureaucrats to enforce announced church policy, one would ordinarily view this not as the legal system in action but as something else, that is, what I call organization control. Following Donald Black, I therefore use "law" only to describe governmental social control. Drawing on a definition of Frank Michelman's, I define a government as a hierarchical organization that is widely regarded as having the legitimate authority to inflict détriments on persons (within its geographically defined jurisdiction) who have not necessarily voluntarily submitted themselves to its authority. ${ }^{13}$

11 These definitions of law and norms correspond moderately well to current usage in American sociology. For example, Donald Black defines "law" as governmental social control. See Black, supra note 7, at 2 . Sociologists are still struggling with how to define "norms." See George C. Homans, The Human Group 121-25 (1950); and John F. Scott, The Internalization of Norms 67-81 (1971). Some sociologists, particularly Continental ones, use "norm" to denote what I mean by "rule."

12 Max Weber, On Law in Economy and Society 5 (Max Rheinstein ed. 1954). See also Anthony T. Kronman, Max Weber 28-31 (1983).

13 Frank I. Michelman, States' Rights and States' Roles: Permutations of "Sovereignty" in National League of Cities v. Usery, 86 Yale L. J. 1165, 1167 (1977). 
Ordinary human conduct will be referred to here as "primary behavior." Social control activity (such as the administration of sanctions), carried out in response to (or in anticipation of) primary behavior, will be termed "secondary behavior.", 14 Rules govern secondary behavior as well as primary behavior. An enforcer who improperly responds to another's primary behavior may himself suffer punishments. Tertiary behavior is social control activity carried out in response to secondary behavior. This classification system could be extended tier by tier, in principle to an infinite number of levels of social control.

These distinctions among different levels of behavior can contribute to a better understanding of how to prove the existence of a rule. ${ }^{15} \mathrm{~A}$ guideline for human conduct is a rule only if the existence of the guideline in fact influences the behavior either of those to whom it is addressed or of those who detect others breaching the guideline. The best and always sufficient evidence that a rule is operative is the routine (although not necessarily inevitable) administration of sanctions, whether rewards or punishments, on people detected breaking the rule. ${ }^{16}$ For example, the best evidence of a primary rule against dishonesty is a pattern of secondary behavior: the regular punishment of people discovered to be dishonest. ${ }^{17}$ Conversely, the total absence of enforcement actions against detected violators of a guideline is conclusive evidence that the guideline is not a rule.

An operative punishment-triggering rule may be so effective that it is never violated. There might then be no enforcement activity to observe to prove the rule's existence. In these situations other, less reliable evidence

14 I borrow these adjectives from H. L. A. Hart, The Concept of Law 89-96 (1961) (distinction between primary and secondary rules). My typology of rules differs from Hart's, however, and I disagree with him on some issues. See note 33 infra.

15 Hart lucidly discusses how to prove the existence of rules in id. at 9-25. See also Émile Durkheim, The Division of Labor in Society 424-35 (George Simpson trans. 1933).

${ }^{16}$ Compare Robert Axelrod, An Evolutionary Approach to Norms, 80 Am. Pol. Sci. Rev. 1095, 1097 (1986): "A norm exists in a given social setting to the extent that individuals usually act in a certain way, and are often punished when seen not to be acting in this way"; Homans, supra note 11, at 123: "A norm, then, is an idea in the minds of the members of a group, an idea that can be put in the form of a statement specifying what the members or other men should do, ought to do, are expected to do, under given circumstances. . . . But even this definition is too broad and must be limited further. A statement of the kind described is a norm only if any departure of real behavior from the norm is followed by some punishment." These definitions show how estimable scholars of social control have tended to overemphasize the role of negative reinforcement and hence to slight the role of rewardtriggering norms. But see $i d$. at 297.

17 Rewards can be used to create incentives for honesty. But if most people are honest most of the time, punishing the dishonest is likely to be administratively cheaper. See text at notes 7-9 supra. 
may prove the existence of a rule. ${ }^{18}$ For example, an observer may sometimes be justified in inferring primary rules from patterns of primary behavior. Thus an alien who visited England could infer, without observing any enforcement activity, that there are rules that people should shake hands with their right hands but drive on the left side of the road. Observing primary behavior is, however, a risky way of determining the rules that govern primary behavior. False negatives and false positives are both possible. A false negative is most likely when detection of acts of deviancy is extremely difficult, but there is nevertheless an operative punishment-triggering rule that is regularly enforced against the few discovered deviants. ${ }^{19}$ For example, if the IRS were regularly to treat proven income from tips as taxable income, then that would be an operative rule even though few tips are in fact reported as income because IRS agents are rarely able to prove who received tips. False positives are possible because not all behavior is normatively constrained. That people regularly sleep does not indicate that there is a rule that they should sleep. Only the regular punishment of detected nonsleepers or the regular rewarding of sleepers would provide ironclad evidence that rules govern the primary activity of sleeping. ${ }^{20}$

People often make aspirational statements about appropriate human conduct. These statements appear in statutes, in rule books for games, in association bylaws, in the adages of everyday speech, and so on. An aspirational statement is evidence of an operative rule but evidence that is rebutted when patterns of primary or secondary behavior flout the aspirational statement. What people do should be taken as more significant than what they say. For example, a criminal statute that prohibits unmarried adults from fornicating is not a rule as that term is used here if detected violators would not regularly be punished. Similarly, Polonius's adage, "Neither a borrower, nor a lender be, ,"21 suggests a normatively appropriate course of primary behavior, but patterns of both primary and secondary behavior show that it is not a rule in the United States today. Aspirational statements are likely to provide the best evidence of rules only when patterns of primary and secondary behavior are unknown. For ex-

18 A pattern of enforcement is thus a sufficient, but not a necessary, condition for the existence of a rule. But compare Scott, supra note 11, at 72 (defining norms solely as patterns of sanctions).

19 When the surpassing of a reward-triggering rule is regularly rewarded, by contrast, one can more confidently predict that primary behavior rarely surpasses the rule; unlike deviants, surpassers typically have incentives to make their activities known.

20 Compare Weber, supra note 12, at 2-5 (comparing conventions-patterns of behavior whose violation will result in significant disapproval from others-with customs-regular patterns of behavior that lack this normative underpinning).

21 William Shakespeare, Hamlet, act 1, sc. 3. 
ample, because little is known of ancient times, the Ten Commandments and equivalent aspirational statements in the sacred texts of other cultures are (weak) evidence of rules that prevailed in antiquity.

A rule can exist even though the people influenced by the rule are unable to articulate the rule in an aspirational statement. Children can learn to speak a language correctly without being able to recite any rules of grammar. Adults who daily honor a complex set of norms that govern dress would be startled if asked to lay out the main principles that constrain their choice of apparel. Rural residents of Shasta County had trouble articulating the norms that governed how they shared the costs of boundary fences. An observer of regular patterns of secondary (and perhaps primary) behavior may nevertheless be able to identify the content of unarticulated rules.

The existence of legal rules is usually easier to prove than is the existence of norms. Court dockets, police reports, and the like reveal lawenforcement efforts, and a law library contains most of the relevant (if often ambiguous) aspirational statements.

Norms are harder to verify because no particular individuals have special authority to proclaim norms and because the enforcement of norms is highly decentralized. After studying Shasta County I nevertheless became willing to assert that rural residents there honor a norm that an owner of livestock is responsible for the conduct of his animals. ${ }^{22}$ The fact that many of the people I interviewed said that a good neighbor would supervise his livestock was only weak evidence of the norm. That most of them did mind their animals said only a little more. The best evidence that this norm existed was that Shasta County residents regularly punished, with gossip and ultimately with violent self-help, ranchers who failed to control cattle.

\section{Controllers' Sanctions: Of State Enforcement and Self-Help}

The five controllers that provide rules of behavior-namely, the actor himself, the person acted on, social forces, nongovernmental organizations, and governments-also administer the rewards and punishments that are essential to the operation of a system of social control. I refer to the sanctions administered by these five controllers, respectively, as (1)

\footnotetext{
22 The content of this particular norm should gladden normative analysts who believe, often for different reasons, that civil obligations should rest on principles of strict liability. See, for example, Guido Calabresi \& Jon Hirschoff, Toward a Test for Strict Liability in Torts, 81 Yale L. J. 1055 (1972); and Richard A. Epstein, A Theory of Strict Liability 2 J. Legal Stud. 151 (1973).
} 
TABLE 1

Elements of a Comprehensive System of Social Control

\begin{tabular}{|c|c|c|c|}
\hline Controller & Rules & Sanction & Combined System \\
\hline $\begin{array}{l}\text { First-party control: } \\
\text { Actor } \\
\text { Second-party con- }\end{array}$ & Personal ethics & Self-sanction & Self-control \\
\hline acted on & Express contracts & Personal self-help & $\begin{array}{l}\text { Promisee-enforced } \\
\text { express contracts }\end{array}$ \\
\hline $\begin{array}{l}\text { Third-party control: } \\
\text { Social forces }\end{array}$ & Norms & Vicarious self-help & Informal control \\
\hline Organization & Organization rules & $\begin{array}{l}\text { Organization } \\
\text { enforcement }\end{array}$ & $\begin{array}{l}\text { Organization } \\
\text { control }\end{array}$ \\
\hline Government & Law & State enforcement & Legal system \\
\hline
\end{tabular}

self-sanctions, (2) personal self-help, (3) vicarious self-help, ${ }^{23}$ (4) organization enforcement, and (5) state enforcement.

Table 1 summarizes the terms for the various controllers' rules and sanctions and also supplies terms to describe a particular controller's combined system. As the table indicates, "informal control" will be used here to describe the system of control that arises out of the operation of decentralized social forces. Thus "social control" will retain its conventional usage in sociology to denote the global system that results from the work of all five controllers.

The controller that makes a rule is commonly the controller that enforces it. This follows from the proposition that the best evidence of a rule is a pattern of regular enforcement. Nevertheless, different controllers can combine their efforts in countless ways to produce hybrid systems of social control. In particular, one controller can consciously enforce another controller's aspirational statements. Thus private citizens may become vigilantes who use self-help to enforce substantive legal rules. ${ }^{24}$ Conversely, police officers may mostly apply norms and personal ethics, not "the book," in their everyday work. ${ }^{25}$ When courts look to business

\footnotetext{
23 "Self-help" literally denotes a person's efforts to square his accounts with others. This same compound word has also rather misleadingly been the traditional legal and sociological label for sanctions administered by friends, relatives, gossips, vigilantes, and other nonhierarchical third-party enforcers. Deferring to this tradition, I use "self-help" to denote both methods of enforcement and employ the adjectives "personal" and "vicarious" to distinguish the second-party and the third-party varieties.

${ }^{24}$ See William M. Landes \& Richard A. Posner, The Private Enforcement of Law, $4 \mathrm{~J}$. Legal Stud. 1 (1975).

${ }^{25}$ See Donald Black, The Manners and Customs of the Police 180-86 (1980).
} 
custom to flesh out incomplete express contracts, the state is enforcing norms created by social forces. ${ }^{26} \mathrm{~A}$ person who has "internalized" a social norm is by definition committed to self-enforcement of a rule of the informal control system. An arbitrator who applies personal ethics in making an award may ultimately rely on the state to enforce the award.

Feedback loops may help to harmonize the rules of different controllers. For example, one function of a contract may be to crystallize substantive entitlements that other sources conferred in uncrystallized form. As another example, political forces may limit the deviation of law from norms.

\section{Five Types of Rules of Conduct}

One last taxonomy will complete the dissection of the social control system. I identify five types of rules of conduct that apply to distinguishable categories of human behavior. The five types of rules are (1) substantive rules, (2) remedial rules, (3) procedural rules, (4) constitutive rules, and (5) controller-selecting rules. ${ }^{27}$ Although each of the five controllers can make all five types of rules, I use only governmental and informal rules-law and norms-as illustrations.

1. Substantive Rules. The core of a system of social control is its substantive rules. These define what primary conduct, that is, conduct unrelated to the making and enforcement of rules, is to be punished, rewarded, or left alone.

2. Remedial Rules. The substantive rules that trigger the administration of sanctions indicate only whether a reward or a punishment is to be dispensed when the trigger is tripped but say nothing about the nature and magnitude of the sanction to be administered. A system of social control therefore must include remedial rules that govern these questions. Remedial rules constrain all enforcement activity whatever the type of rule whose breach has triggered activity from enforcers. ${ }^{28}$

Remedial laws include the legal rules on remedies and other legal rules, such as rules of self-defense, that are more traditionally viewed as part of the substantive law. ${ }^{29} \mathrm{I}$ discovered analogous remedial norms in Shasta

${ }^{26}$ See Elizabeth Warren, Trade Usage and Parties in the Trade: An Economic Rationale for an Inflexible Rule, 42 U. Pitt. L. Rev. 515 (1981).

${ }^{27}$ Each of these types of rules can be subclassified into reward-triggering rules and punishment-triggering rules. See Figure 1 and text at note 7 supra.

28 For example, remedial rules constrain tertiary behavior provoked by inappropriate secondary behavior. Remedial rules also constrain enforcers' responses to breaches of procedural, constitutive, and controller-selecting rules.

29 The right of self-defense, recognized in the common law of battery, is a remedial rule because it is applied to evaluate the propriety of a threatened person's response to another's prior (or anticipated) aggression. 
County. For example, a victim of a series of cattle trespasses is supposed to exhaust less drastic self-help measures before resorting to violence against the trespassing animals. ${ }^{30}$

3. Procedural Rules. Procedural rules govern how controllers are to obtain and weigh information before deciding whether to administer sanctions in particular instances. Codes of evidence and civil procedure contain basic procedural laws. An example of a procedural norm would be an informal rule on the quality of evidence that an aggrieved person must have before being entitled to spread negative gossip about another's wrongdoing.

4. Constitutive Rules. Constitutive rules govern the internal structures of controllers. In the legal system, for example, constitutive rules determine the structure and interrelations of the various branches of government. The constitutive rules of the legal system are mostly governmental in source but not invariably so. Current examples of operative constitutive norms at the federal level are the practice of senatorial courtesy and the unwritten rule that the votes of four of the nine members of the Supreme Court are needed to grant a writ of certiorari.

Constitutive rules also help structure the informal system of social control. For instance, constitutive norms may encourage members of a group not to be loners but rather to entangle themselves in the sorts of continuing relationships that help foster cooperative behavior.

The constitutive rules of organizations typically arise from a number of sources. Statutes often constrain the governance structures that the promoter of a new organization may use. Within these legal constraints the promoter drafts documents, such as articles of incorporation, that establish a governance structure. Some of the basic provisions in these documents typically cannot be amended without the unanimous consent of members. For example, each member of a homeowners association usually has the right to veto a proposed reallocation of votes or assessments. ${ }^{31}$ Constitutive rules of this nature are contractual rules because each member expressly agrees to their content. Because unanimity is hard to achieve, the governing documents of organizations commonly authorize a supermajority of members, or perhaps even an elected board of directors, to change some rules that bind all members. Rules adopted in this fashion are organizational rules, not contracts, because dissenting members are coerced. For example, if the board of directors of a homeowners association were to approve a bylaw that governed when

${ }^{30}$ Ellickson, supra note 3, at 676-79.

31 See Robert C. Ellickson, Cities and Homeowners Associations, 130 U. Pa. L. Rev. $1519,1532(1982)$. 
and where the general membership would hold its meetings, that constitutive rule should be viewed as an organizational rule, not as a contract among the organization's members. ${ }^{32}$

5. Controller-selecting Rules. The crucial role of controllerselecting rules-the fifth and last category of rules-has gone little noticed. ${ }^{33}$ In a society replete with governments, private organizations, social forces, contractual arrangements, and individuals potentially capable of self-control, there must be rules that decide, for each domain of human activity, the division of social control labor among the various controllers. Controller-selecting rules perform this function. They coordinate, for example, the social control responsibilities of the visible sovereigns that make and enforce laws with the social control responsibilities of the invisible sovereigns that make and enforce norms.

All five controllers can make controller-selecting rules. When someone's personal ethics tell him to ignore a loss inflicted by another, he has selected the other party's self-control system as the sole source of social control. An arbitration contract is a second-party device for selecting a social control system. A controller-selecting norm in rural Shasta County told rural residents to use norms and self-help to resolve cattle-trespass disputes and not to refer those disputes to the legal system.

An example from academic life will illustrate the function of an organization's controller-selecting rules. Suppose a law student were arguably to have plagiarized library sources during the preparation of a paper. The law school's staff would apply controller-selecting rules to determine where to find rules on what constitutes plagiarism and how plagiarists should be punished. These controller-selecting rules might point to the application of university standards and sanctions for plagiarism-an example of the use of contractual and/or organizational controls. If the law school relied entirely on a student's own individual conscience to control plagiarism, it would be selecting the self-control system as the exclusive controller. If the school publicized the case among the students, it would be choosing the informal enforcement of norms as the system of social control. Finally, if the copying violated a plagiarized author's legal rights in intellectual property, the law school might conceivably allocate the plagiarism dispute to the legal system for resolution.

Some analogies may help clarify the role of controller-selecting rules. These rules are a bit like the system programs that computers use to

\footnotetext{
${ }^{32}$ See id. at 1529-39.

${ }^{33}$ Hart suggested that operation of the legal system requires a variety of what he called "secondary rules." Some that he identified are analogous to what I call constitutive and controller-selecting rules. See Hart, supra note 14, at 74-76, 89-94, 97-107. Yet Hart oddly asserted that only the legal system needs secondary rules. See id. at 113-14, 151 .
} 
operate other programs. They are also like the choice-of-law and jurisdictional rules that courts use to decide, respectively, which government's law is to be applied and which government is to be responsible for imposing sanctions. Controller-selecting rules, however, address questions prior to the ones that choice-of-law and jurisdictional laws reach, that is, not which government's rules and enforcement powers are to be tapped but, rather, whether any government should have a say about the matter at hand. To illustrate their role for a final time, one function of controllerselecting rules is to demarcate the boundary of the shadow of the law. ${ }^{34}$

If the controller-selecting rule of any controller disfavors the legal resolution of a dispute, the dispute is unlikely to enter the legal system. For example, if controller-selecting norms were to point away from governmental involvement in settlement of a dispute, a party would be reluctant, because of likely informal sanctions, to knock on the courthouse door. Similarly, if controller-selecting laws were to deny the court jurisdiction over the matter because, say, it was "nonjusticiable," then a judge would not let a knocking party in.

\section{The Scope of a General Theory of Social Control}

On the basis of independent variables describing a society, a general theory of social control would predict the content of the society's rules, whether they be substantive, remedial, procedural, or controller selecting. ${ }^{35}$ Because a society's operative rules are best revealed by the characteristics of the events that regularly trigger enforcement activity, ${ }^{36}$ the general theory would thus predict which events would trigger sanctions, what the sanctions would be, how controllers would gather information, and which controller would administer sanctions in a given instance. To put forth even a rudimentary theory an analyst would have to incorporate theories of the behavior of the five controllers. In other words, a general theory of social control requires subtheories of human nature, of market transactions, of social interactions, of organizations, and of governments. For starters a theorist thus needs a command of psychology, economics, sociology, organization theory, and political science.

\footnotetext{
34 The source of the metaphor is Robert H. Mnookin \& Lewis Kornhauser, Bargaining in the Shadow of the Law: The Case of Divorce, 88 Yale L. J. 950 (1979). Because divorces must be processed through the legal system, those authors had no occasion to observe that, in some other contexts, controllers other than the state set and enforce the original entitlements of bargainers.

${ }^{35}$ Because the theory of social control is so little developed, in their beginning ventures theorists would likely treat as exogenous independent variables the constitutive rules that determine group boundaries and controller structures and would attempt to predict only the content of the four remaining types of rules.

${ }^{36}$ See text at notes 15-22 supra.
} 
No small challenge, this. My object in the balance of this paper is more modest. To suggest the utility of the taxonomy just developed, I will employ parts of it to highlight major shortcomings in mainstream law-andeconomics and law-and-society theories of social control.

\section{Beyond Legal Centralism: The Shortcomings of LAW-AND-ECONOMICS THEORY}

Most law-and-economics scholars and other legal instrumentalists have underappreciated the role that nonlegal systems play in achieving social order. ${ }^{37}$ Their articles are full of law-centered discussions of disputes, such as cattle trespass disputes between farmers and ranchers, whose resolution is in fact largely beyond the influence of governmental rules. There are, of course, notable exceptions. Law-and-economics stalwarts such as Harold Demsetz and Richard Posner have understood that property rights may evolve in primitive societies without the involvement of a visible sovereign. ${ }^{38}$ Several economists have emphasized that promisees can enforce express contracts without the help of the state. ${ }^{39}$ Yet many scholars who work in law and economics still seem to regard the state as the dominant, perhaps even the exclusive, controller.

\section{A. The Legal-Centralist Tradition}

Economist Oliver Williamson has used the phrase "legal centralism" to describe the belief that governments are the chief sources of rules and enforcement efforts. ${ }^{40}$ The quintessential legal centralist was of course Thomas Hobbes. Hobbes thought that in a society without a sovereign all would be chaos. To quote some of Hobbes's best-known lines, without Leviathan one would observe

continual feare, and danger of violent death; And the life of man, solitary, poore, nasty, brutish, and short. .. . To this warre of every man against every man, this is also consequent; that nothing can be Unjust. The notions of Right and Wrong,

37 This is hardly an original point. See, for example, Lon L. Fuller, Human Interaction and the Law, in The Rule of Law 171 (Robert Paul Wolff ed. 1971); and John Griffiths, Is Law Important? 54 N.Y.U. L. Rev. 339 (1979).

38 See Harold Demsetz, Toward a Theory of Property Rights, 57 Am. Econ. Rev. Papers \& Proc. 347, 350-53 (1967) (development of fur trade led Labrador Indians to establish tradition of exclusive privileges to use hunting territories); and Richard A. Posner, The Economics of Justice, chs. 5-8 (1981) (economic analysis of order in primitive societies).

${ }^{39}$ See, for example, Benjamin Klein \& Keith B. Leffler, The Role of Market Forces in Assuring Contractual Performance, 89 J. Pol. Econ. 615 (1981); and Oliver E. Williamson, Credible Commitments: Using Hostages to Support Exchange, 73 Am. Econ. Rev. 519 (1983). See generally Anthony T. Kronman, Contract Law and the State of Nature, $1 \mathrm{~J} . \mathrm{L}$. Econ. \& Org. 5 (1985).

40 Williamson, supra note 39 , at $520,537$. 
Justice and Injustice have no place. Where there is no common Power, there is no Law; where no Law, no Injustice. . . . It is consequent also to the same condition, that there be no Propriety, no Dominion, no Mine and Thine distinct; but only that to be every mans that he can get; and for so long, as he can keep it. ${ }^{41}$

Hobbes apparently saw no possibility that some nonlegal system of social control, such as the decentralized enforcement of norms, might bring about at least a modicum of order even under conditions of anarchy. (The term "anarchy" is used here in its root sense of a lack of government rather than in its vulgar sense of a state of disorder. Only a legal centralist would equate the two.)

The seminal works in law and economics hew to the Hobbesian tradition of legal centralism. Economist Ronald Coase's work is an interesting example. Throughout his scholarly career, Coase has emphasized the capacity of individuals to work out mutually advantageous arrangements without the aid of a central coordinator. Yet in his famous article The Problem of Social Cost, Coase fell into a line of analysis that was wholly in the Hobbesian tradition. In analyzing the effect that changes in law might have on human interactions, Coase implicitly assumed that governments have a monopoly on rule-making functions. In a representative passage, Coase wrote, "It is always possible to modify by transactions on the market the initial legal delimitation of rights. And, of course, if such market transactions are costless, such a rearrangement of rights will always take place if it would lead to an increase in the value of production" (emphasis added). ${ }^{42}$ Even in the parts of his article where he took transaction costs into account, Coase failed to note that in some contexts rights themselves might initially be delimited not by visible sovereigns but rather through decentralized norm-making processes.

In another of the classic works in law and economics, Calabresi and Melamed similarly regard "the state" as the sole source of social order:

The first issue which must be faced by any legal system is one we call the problem of "entitlement." Whenever a state is presented with the conflicting interests of two or more people, or two or more groups of people, it must decide which side to favor. Absent such a decision, access to goods, services, and life itself will be decided on the basis of "might makes right"- - whoever is stronger or shrewder will win. Hence the fundamental thing that the law does is to decide which of the conflicting parties will be entitled to prevail.

Having made its initial choice, society must enforce that choice. Simply setting the entitlement does not avoid the problem of "might makes right"; a minimum of

\footnotetext{
${ }^{41}$ Hobbes, supra note 1, at 97-98; see also id. at 110-13 (only a state can force parties to abide by their covenants).

42 Ronald H. Coase, The Problem of Social Cost, 3 J. Law \& Econ. 1, 15 (1960).
} 
state intervention is always necessary. Our conventional notions make this easy to comprehend with respect to private property. If Taney owns a cabbage patch and Marshall, who is bigger, wants a cabbage, he will get it unless the state intervenes. ${ }^{43}$

Although they doubtless know better, in these passages Calabresi and Melamed lapse into an extreme legal centralism that denies the possibility that controllers other than "the state" can generate and enforce entitlements. ${ }^{44}$

Economists have hardly been alone in exaggerating the state's role in making and enforcing rules of order. Max Weber and Roscoe Pound, for example, have both authored passages that seemingly endorse the dubious propositions that the state has, and should have, a monopoly on the use of violent force. ${ }^{45}$ As both those scholars recognized elsewhere in their writings, operative rules in human societies in fact often authorize forceful private responses to provocative conduct.

Perhaps because legal centralists overrate the role of law, they seem unduly prone to assume that actors know and honor legal rules. Economists know that information is costly, and a growing number emphasize that humans have cognitive limitations. ${ }^{46}$ Yet in making assessments of the instrumental value of alternative legal approaches, respected law-andeconomics scholars have assumed that drivers and pedestrians are fully

43 Guido Calabresi \& A. Douglas Melamed, Property Rules, Liability Rules, and Inalienability: One View of the Cathedral, 85 Harv. L. Rev. 1089, 1090-91 (1972).

44 Calabresi and Melamed's assertion that anarchic entitlements are highly correlated with a party's individual power is plausible for entitlements created through promiseeenforced contracts. Norms, by contrast, are less likely to bestow rights in proportion to individual might; many self-help enforcers can gang up on a mighty bully.

45 Weber regarded the state as the supreme instrument of social control: "[T]he modern state is a compulsory association which organizes domination. It has been successful in seeking to monopolize the legitimate use of physical force as a means of domination within a territory. . . . The right to use physical force is ascribed to other institutions or to individuals only to the extent to which the state permits it." Max Weber, Essays in Sociology 78, 83 (H. Gerth \& C. Wright Mills trans. 1958). In reality, no state has been able to prevent other controllers from using violence to enforce rules of behavior. See also Taylor, supra note 10, at 4-5 (criticizing Weber's position). Pound's legal-centralist tendencies are revealed in the following passage: "It is a general principle that one who is or believes he is injured or deprived of what he is lawfully entitled to must apply to the state for help. Self help is in conflict with the very idea of the social order. It subjects the weaker to risk of the arbitrary will or mistaken belief of the stronger. Hence the law in general forbids it." 5 Roscoe Pound, Jurisprudence $\$ 142$, at 351-52 (1959). But see id. at 349, 352, 356 (acknowledging legal recognition of limited rights to exercise self-help). Compare Robert Nozick, Anarchy, State, and Utopia $12-15,26,34-35,88-89,138-39$ (1974) (even an ultraminimal state should sharply limit self-help because of danger that punishment will be wrongly inflicted).

${ }^{46}$ See, for example, George J. Stigler, The Economics of Information, 69 J. Pol. Econ. 213 (1961); George A. Akerlof \& William T. Dickens, The Economic Consequences of Cognitive Dissonance, 72 Am. Econ. Rev. 307 (1982); and Herbert A. Simon, Reason in Human Affairs 3-35, (1983). 
aware of the substance of personal-injury law $;^{47}$ that, when purchasing a home appliance whose use may injure bystanders, consumers know enough products-liability law to be able to assess the significance of a manufacturer's warranty provision that disclaims liability to bystanders; ${ }^{48}$ and that people who set fires fully understand the rules of causation that courts apply when two fires, one natural and the other man-made, conjoin and do damage. ${ }^{49}$

\section{B. Some Evidence That Refutes Legal Centralism}

Much of the evidence I gathered in Shasta County refutes legal centralism. ${ }^{50}$ When adjoining landowners there decided how to split the costs of boundary fences, they reached their solutions in almost total ignorance of their substantive legal rights. Moreover, as already noted, when resolving cattle trespass disputes, virtually all rural residents applied a norm that an animal owner is responsible for the behavior of his livestock, even in situations where they knew that a cattleman would not be legally liable for trespass damages. Although I found that governmental rules and processes were often important in the resolution of disputes arising out of highway collisions between vehicles and livestock, even in those situations most rural residents badly misperceived the applicable substantive law. As I will now show, other empiricists have come up with analogous findings.

\section{Substantive Norms Often Supplant Substantive Laws}

Law-and-society scholars have long known that in many contexts people look primarily to norms, not to law, to determine substantive entitlements. In a path-breaking study published in 1963, Stewart Macaulay found that norms of fair dealing constrained the behavior of Wisconsin business firms at least as much as did substantive legal rules. ${ }^{51} \mathrm{H}$. Laur-

47 A. Mitchell Polinsky, An Introduction to Law and Economics 37-49 (1983).

48 George L. Priest, A Theory of the Consumer Product Warranty, 90 Yale L. J. 1297, 1350 (1981).

49 Steven Shavell, An Analysis of Causation and the Scope of Liability in the Law of Torts, 9 J. Legal Stud. 463, 471, 495 (1980).

so See Ellickson, supra note 3; and my forthcoming book.

51 Stewart Macaulay, Non-contractual Relations in Business: A Preliminary Study, 28 Am. Soc. Rev. 55 (1963). For additional discussion of Macaulay's findings, see text at notes 108-9 infra. Others have replicated Macaulay's general finding that norms and self-help are mainly what bring civility to business relations. See Sally Falk Moore, Law and Social Change: The Semi-autonomous Social Field as an Appropriate Subject of Study, 7 Law \& Soc'y Rev. 719, 723-29 (1973) (study of "better" women's dress industry); Thomas M. Palay, Comparative Institutional Economics: The Governance of Rail Freight Contracting, 
ence Ross's study of how insurance adjusters settled claims arising from traffic accidents similarly found that the law in action differed substantially from the law on the books. For example, Ross discovered that adjusters applied rules of comparative negligence even in jurisdictions where the formal law made contributory negligence a complete defense..$^{52}$

Vilhelm Aubert investigated the effect of the Norwegian Housemaid Law of $1948 .^{53}$ That statute limited a maid's working hours to a maximum of ten hours per day, gave maids entitlements to holidays and overtime pay, and imposed other labor standards on employers of housemaids. Although the ceiling of ten hours per working day was violated in about half the households studied and the overtime pay provisions in almost 90 percent, Aubert found that no lawsuits had been brought under this statute within the first two years of its enactment. Aubert concluded that a housemaid's basic mechanism for controlling employer abuse was a nonlegal one, namely, her power to exit the relationship by obtaining employment in another household. He concluded that the statute's effect had been modest at most. ${ }^{54}$

Ross and Littlefield, in a more recent study, found that a mass retailer of household appliances in Denver was much more solicitous of complaining customers than the law required. ${ }^{55}$ For example, the retailer would often refund a buyer's money, no questions asked, when it was not legally compelled to do so.

When Steven Cheung investigated the supply of bees for Washington orchards, he found that orchard owners basically relied not on formal contracts but on a custom that each of them should provide bees in proportion to the number of fruit trees owned. ${ }^{56}$

John Phillip Reid has described how norms brought about order in a virtually Hobbesian environment. 57 . In the mid-nineteenth century thousands of pioneers took the Overland Trail from Missouri to the West.

13 J. Legal Stud. 265 (1984); and James J. White, Contract Law in Modern Commercial Transactions, 22 Washburn L. J. 1 (1982) (contract law did not influence how chemical companies allocated supply during shortages).

52 H. Laurence Ross, Settled out of Court 240-41, 275-76 (rev. ed. 1980).

53 Vilhelm Aubert, Some Social Functions of Legislation, 10 Acta Sociologica 98 (1967).

54 See also Note, Alterations Needed: A Study of the Disjunction between the Legal Scheme and Chinatown Garment Workers, 36 Stan. L. Rev. 825 (1984) (garment workers do not invoke rights conferred under labor-standards legislation).

55 H. Laurence Ross \& Neil O. Littlefield, Complaint as a Problem-solving Mechanism, 12 Law \& Soc'y Rev. 199 (1978).

56 Steven N. S. Cheung, The Fable of the Bees: An Economic Investigation, 16 J. Law \& Econ. 11, 30 (1973).

57 John Phillip Reid, Law for the Elephant: Property and Social Behavior on the Overland Trail 339-40 (1980). 
Particularly in the mid-1840s the situation on the trail was nearly anarchic; the identity of the national sovereign of much of the territory was disputed, and no sovereign had law-enforcement agents in the area. According to Reid, travelers on the Overland Trail nonetheless demonstrated a strong respect for conventional norms of property. For example, travelers who lacked vital goods typically felt constrained to buy, not to take, what they needed from others.

Laboratory evidence also casts doubt on legal centralism. ${ }^{58}$ Hoffman and Spitzer fortuitously discovered the importance of substantive norms during their laboratory experiments on the dynamics of Coasean bargaining. In an early experiment Hoffman and Spitzer endowed their laboratory-game players with unequal initial monetary entitlements. ${ }^{59}$ The game rules allowed the players to negotiate contracts that would increase their joint monetary proceeds from the game. The contracts could include provisions for side payments. Hoffman and Spitzer expected to observe only Pareto-superior contracts, that is, ones under which no party to the contract would come out monetarily worse off. In the two-person games, most players (especially those who knew that they would play against each other at least twice) were instead inclined to split equally the gross proceeds from a game, even when an equal split was Pareto inferior for one of them. Intrigued by this result, Hoffman and Spitzer conducted another experiment that they concluded revealed that a set of informal norms, what they called "Lockean ethics," helped govern when players were prone to equalize the gross proceeds. ${ }^{60}$ In short, Hoffman and Spitzer tried to be sovereigns but found that norms (or conceivably personal ethics) often trumped their initial distributions of property rights.

\section{The Pervasiveness of Self-Help Enforcement}

Legal centralists regard governments as the chief enforcers of entitlements. The taxonomy of social control systems in Table 1 identified four other possibilities, namely, self-sanction, personal self-help, vicarious self-help, and organization enforcement. As mentioned, I found that self-

\footnotetext{
${ }^{58}$ See, for example, Leonard Berkowitz \& Nigel Walker, Law and Moral Judgments, 30 Sociometry 410 (1967) (actors' moral opinions are more strongly affected by the moral judgments of their peers than they are by the contents of formal law).

59 Elizabeth Hoffman \& Matthew L. Spitzer, The Coase Theorem: Some Experimental Tests, 25 J. Law \& Econ. 73 (1982).

${ }^{60}$ Elizabeth Hoffman \& Matthew L. Spitzer, Entitlements, Rights, and Fairness: An Experimental Examination of Subjects' Concepts of Distributive Justice, 14 J. Legal Stud. 259 (1985). But see Glenn W. Harrison \& Michael McKee, Experimental Evaluation of the Coase Theorem, $28 \mathrm{~J}$. Law \& Econ. 653 (1985) (attributing some of Hoffman and Spitzer's original results to the small size of the social surplus that players would obtain when moving to the joint maximum).
} 
help was rife in Shasta County. Ranchers who refused to mind their cattle, or to bear a proper share of boundary-fence costs, or to contribute labor to a controlled burn did so at the risk of suffering the sting of negative gossip or some other gentle form of neighbor retaliation. Rural residents were also eventually willing to resort to violent self-help against the trespassing livestock of ranchers who were repeatedly unmindful.

Social scientists increasingly appreciate the importance of self-help. For example, Albert Hirschmann has analyzed how people can use the options of "exit," "voice," and "loyalty" to influence others around them. ${ }^{61}$ The game-theoretic strategy of "Tit-for-Tat," lucidly analyzed by Robert Axelrod, is a self-help strategy for people in continuing relationships. ${ }^{62}$

Sociologists have long been aware of the power of gossip and ostracism. ${ }^{63}$ Donald Black has recently gathered cross-cultural evidence that violent self-help is also common. ${ }^{64}$ Black asserts that much of what is ordinarily classified as crime is in fact retaliatory action aimed at achieving social control. The law itself explicitly authorizes self-help in many situations. Both tort and criminal law, for example, authorize a threatened person to use reasonable force to repel an assailant. ${ }^{65}$ The legal-centralist assertion that the state monopolizes the use of force is, to put it bluntly, absurd. ${ }^{66}$

\section{The Scantiness of Legal Knowledge}

Ordinary people know little of the private substantive law that applies to personal interactions. ${ }^{67}$ Motorists may possibly learn that the failure to

61 Albert O. Hirschman, Exit, Voice, and Loyalty: Responses to Decline in Firms, Organizations and States (1970).

62 Robert Axelrod, The Evolution of Cooperation (1984).

${ }^{63}$ See Sally Engle Merry, Rethinking Gossip and Scandal, in Black ed., supra note 5, at 271.

${ }^{64}$ Donald Black, Crime as Social Control, 48 Am. Soc. Rev. 34 (1983). An expanded version appears in 2 Toward a General Theory of Social Control 1 (Donald Black ed. 1984). See also, for example, Sally Engle Merry, Urban Danger: Life in a Neighborhood of Strangers 178-86 (1981) (role of actual and threatened violent retaliation in multiethnic urban neighborhood); and Suzann R. Thomas-Buckle \& Leonard G. Buckle, Doing unto Others: Disputes and Dispute Processing in an Urban American Neighborhood, in Neighborhood Justice: Assessment of an Emerging Idea 78, 79 (Roman Tomasic \& Malcolm M. Feeley eds. 1982) ("In brief, what we found was reliance on self-help").

${ }^{65}$ See, for example, Kent Greenawalt, Violence-Legal Justification and Moral Appraisal, 32 Emory L. J. 437, 448-66 (1983) (criminal-law rules on self-help).

66 It is more accurate to view the state as a major concentration of the privileged use of force, not as a monopolist thereof. See Taylor, supra note 10, at 4-5.

${ }^{67}$ In some contexts a law may influence the behavior of people ignorant of it. For example, if the tort liabilities of teenage drivers were increased without their knowledge, their liability insurance rates might rise, and fewer teenagers might drive as a result. 
wear a seatbelt is a misdemeanor, but only personal-injury lawyers are likely to know whether the tort law of their state makes an injured motorist's failure to wear a seatbelt a defense in a civil action. First-year law students may complain that what they are encountering is boring but never that it is old hat.

Surveys of popular knowledge of law relevant to ordinary household transactions, such as the leasing of housing or the purchase of consumer goods, invariably show that respondents have scant working knowledge of private law. For example, when interviewers asked some 300 Austin households thirty yes-or-no questions about Texas civil law, "highincome Anglos" answered correctly an average of nineteen out of thirty and "low-income Mexicans" an average of thirteen out of thirty (a performance worse than chance) ${ }^{68}$ Another survey revealed that a solid majority of Texas therapy patients did not know that they were protected by a legal privilege of nondisclosure, perhaps because "[f]or $96 \%$ of the patients the therapist's ethics, not the state of the law, provided assurances of confidentiality. "69 In Vilhelm Aubert's aforementioned study of the Norwegian Housemaid Law of 1948, housemaids and housewives were asked if they were aware of nine specific clauses in the statute, two of which it did not in fact contain. The respondents "recognized" the two fictitious clauses somewhat more frequently than the seven real ones. $^{70}$

Highly educated specialists could be expected to have a somewhat better grasp of the private-law rules that impinge on their professional practices. Givelber, Bowers, and Blitch conducted a national survey of nearly 3,000 therapists to measure knowledge of the California Supreme Court's 1975 Tarasoff decision, which dealt with the tort duties of therapists when patients utter threats against third parties. ${ }^{71}$ They found that although 96 percent of California therapists and 87 percent of therapists in other states knew of the Tarasoff decision by name, the great majority wrongly construed it as imposing an absolute duty to warn rather than a duty to warn only when a warning would be the reasonable response under the circumstances. Many of the therapists were (understandably)

68 Martha Williams \& Jay Hall, Knowledge of the Law in Texas: Socioeconomic and Ethnic Differences, 7 Law \& Soc'y Rev. 99, 113 (1972). See also Note, Legal Knowledge of Michigan Citizens, 71 Mich. L. Rev. 1463 (1973) (questionnaire respondents did better on criminal-law questions than on consumer-law questions).

${ }^{69}$ Daniel W. Shuman \& Myron S. Weiner, The Privilege Study: An Empirical Examination of the Psychotherapist-Patient Privilege, 60 N.C. L. Rev. 893, 925 (1982).

70 Aubert, supra note 53, at 101.

71 Daniel J. Givelber, William J. Bowers, \& Caroly L. Blitch, Tarasoff, Myth and Reality: An Empirical Study of Private Law in Action, 1984 Wis. L. Rev. 443 (1984). 
confused about whether a California Supreme Court decision could impose duties on therapists in other states. Lest law professors be too quick to gloat, they should ask themselves how well they would perform if closely quizzed about their possible civil liabilities for photocopying copyrighted works for inclusion in class materials.

\section{The Infrequent Use of Attorneys to Resolve Disputes}

A person ignorant of law can get help from an attorney. Yet even in the allegedly litigious United States, individuals who have nonbusiness problems are highly unlikely to turn to attorneys either to amplify their legal knowledge or to help pursue a claim. In Barbara Curran's nationwide sample of adults, one-third had never used an attorney during their lifetimes, and almost another third had used an attorney only once. ${ }^{72}$ What prompts someone to take the unusual step of consulting an attorney in a nonbusiness context? Curran found that the most common impetis was not an interpersonal dispute but rather property transfer, that is, buying real estate or planning or settling an estate. ${ }^{73} \mathrm{~A}$ solid majority of American adults apparently go through their lives without ever hiring an attorney to help resolve an interpersonal dispute. ${ }^{74}$ One of Curran's other survey results may help explain this finding. When asked to appraise the statement, "Most lawyers charge more for their services than they are worth," 68 percent of the respondents replied that they agreed with it. ${ }^{75}$

The Civil Liability Research Project (CLRP) is the most ambitious recent empirical study of dispute-resolution practices in the United States. ${ }^{76}$ The CLRP researchers have found that Americans are not reluctant to submit claims for compensation to other parties who they perceive have seriously wronged them. Of these claims, 68 percent result in some

\footnotetext{
72 Barbara A. Curran, The Legal Needs of the Public: The Final Report of a National Survey 186-94 (1977).

${ }^{73}$ Id. at 196. About half of nonbusiness visits to attorneys involve these transactions. Marital matters are the third leading cause of the use of lawyers.

${ }^{74}$ Survey data indicate that about 20 percent of American adults have been parties in civil lawsuits (other than divorce cases). Marc Galanter, Reading the Landscape of Disputes: What We Know and Don't Know (and Think We Know) about Our Allegedly Contentious and Litigious Society, 31 U.C.L.A. L. Rev. 4, 21 (1983). A study of an older, middle-class suburb of New York City found that, during a twelve-month period, middle-class residents initiated just one civil case against neighbors and social acquaintances (a suit by one youth to recover a $\$ 400$ debt owed by another). The suburb had a population of 18,000 . M. P. Baumgartner, Social Control in Suburbia, in Black ed., supra note 64, at 79, 91-93.

75 Curran, supra note 72 , at 231.

76 See generally Special Issue on Dispute Processing and Civil Litigation, pt. 2, The Civil Litigation Research Project, 15 Law \& Soc'y Rev. 485 (1980-81).
} 
sort of compensation being paid to the claimant. ${ }^{77}$ Yet the CLRP data indicate that, even when a claim for over $\$ 1,000$ has been initially rejected, in only 10-20 percent of cases will a claimant employ an attorney to help resolve the dispute. ${ }^{78}$ If personal injury and alimony disputes were to be excluded from the sample, the frequency of attorney use would be much lower still. ${ }^{79}$

In short, most people know little private law and are not much bothered by their ignorance. Their experience tells them that the basic rules that govern ordinary interpersonal affairs are not in the law books anyway. This reality need not dispirit scholars who are inclined to use economic analysis to study social order. As law-and-economics scholars continue to shed the legal-centralist tradition, they may well find that by applying game theory, transaction-cost economics, and similar tools, they can develop a more powerful positive explanation of the division of social control labor than scholars in other schools have yet been able to develop.

\section{Beyond Exogenous Norms: The Shortcomings of LAW-AND-SOCIETY THEORY}

In contrast to the law-and-economics scholars, law-and-society scholars have long been aware that norms and self-help play important roles in coordinating human affairs. Perhaps because their vision of reality is so rich, however, sociologists and their allies have been handicapped because they do not agree on, and often do not show much interest in developing, basic theoretical building blocks. ${ }^{80}$ Anyone who widely reads in both law-and-economics and law-and-society literature is bound to come away feeling that economists, although often dismayingly blind to realities, are clearer, more scientific, and more successful in building on prior work. The late Arthur Leff, who read extensively in both, called law-and-economics a desert and law-and-society a swamp. ${ }^{81}$ Having probed the causes of the aridity, I now inquire into the causes of the swampiness.

${ }^{77}$ Richard E. Miller \& Austin Sarat, Grievances, Claims, and Disputes: Assessing the Adversary Culture, 15 Law \& Soc'y Rev. 525, 537 (1980-81), corrected in Richard E. Miller, Erratum, 17 Law \& Soc'y Rev. 653 (1983).

${ }^{78}$ Id. at 546.

79 Id. at 537.

80 See George C. Homans, Coming to My Senses: The Autobiography of a Sociologist 333-48 (1984). But compare Clifford Geertz, The Interpretation of Cultures 21-22 (1973) (anthropologist's warning of the dangers of the cross-cultural models); Arthur A. Leff, Law And, 87 Yale L. J. 989 (1978) (law professor's doubts about the possibility of positivist science).

81 Personal communication, January 1985, from Stan Wheeler, who told me that Leff made this remark to him in a casual conversation. 


\section{A. Sociological Theories of the Interaction of Law and Norms}

\section{Legal Peripheralism and Evidence That Refutes It}

Some sociologists are extreme legal peripheralists who dismiss the legal system as utterly uninfluential. Legal peripheralism dates back at least to the Roman historian Tacitus, who is still quoted for having asked, "Quid leges sine moribus?" ("What are laws without morals?") This view was particularly popular a century ago, when the social Darwinist William Graham Sumner was emphasizing the role that "folkways" played in achieving social order. ${ }^{82}$

Extreme legal peripheralism is as untenable as is extreme legal centralism. Although law may often be overrated as an instrument of social engineering, it is not invariably toothless. For example, after the Russian Revolution the Communists who took over the state apparatus were eventually able to use law to alter (although hardly totally to transform) life in Moslem central Asia. ${ }^{83}$ Similarly, most observers would agree that changes in federal civil rights law during the 1950 s and the 1960 s helped to undercut social traditions of racial segregation in the South.

Focused field studies of the effect of changes in private substantive law also refute extreme legal peripheralism. I found that the adoption of closed-range ordinances in Shasta County deterred some ranchers from running their herds at large because they thought that the ordinances would increase their liabilities to motorists who collided with their cattle. Prior empirical studies have found, among other things, that the allocation of legal property rights in the intertidal zone affects labor productivity in the oyster industry, ${ }^{84}$ that the structure of workers' compensation systems influences the frequency of workplace fatalities, ${ }^{85}$ and that the content of medical malpractice law has an effect on how claims are settled. ${ }^{86}$

82 William G. Sumner, Folkways 55 (1906). More recent examples of legal peripheralism include Robert Bierstedt, The Social Order 223-24 (3d ed. 1970); and Burton M. Leiser, Custom, Law and Morality (1969).

${ }^{83}$ Gregory J. Massell, The Surrogate Proletariat: Moslem Women and Revolutionary Strategies in Soviet Central Asia, 1919-1929 (1974); Gregory J. Massell, Law as an Instrument of Revolutionary Change in a Traditional Milieu: The Case of Soviet Central Asia, 2 Law \& Soc'y Rev. 179 (1968). Massell emphasized the failure of Soviet law to bring about rapid revolutionary change but nevertheless identified some consequences of the legal intervention.

84 Richard J. Agnello \& Lawrence P. Donnelley, Property Rights and Efficiency in the Oyster Industry, $18 \mathrm{~J}$. Law \& Econ. 521 (1975).

85 James R. Chelius, Liability for Industrial Accidents: A Comparison of Negligence and Strict Liability Systems, 5 J. Legal Stud. 293 (1976).

${ }^{86}$ Patricia Munch Danzon \& Lee A. Lillard, Settlement out of Court: The Disposition of Medical Malpractice Claims, 12 J. Legal Stud. 345 (1983). 
The mainstream law-and-society position today seems to be the sensible one that both law and norms can influence behavior. ${ }^{87}$

\section{Theories of the Division of Social Control Labor}

Because law-and-society scholars have appreciated that informal controls always supplement and often supplant the legal system, they have concerned themselves with the interplay between the legal system and less formal systems of social control. Donald Black's The Behavior of Law is the most ambitious overarching attempt to identify formally the variables that affect to what degree particular disputes fall within the shadow of the law. ${ }^{88}$ John Griffiths and William Felstiner have also written insightfully about the division of social control labor ${ }^{89}$ In a more particular context, Stewart Macaulay, Ian Macneil, and others recognized (before any law-and-economics scholars did) that the presence of a continuing relationship would vitally influence how the parties to a contract would resolve their disputes. ${ }^{90}$ Law-and-society scholars would be the first to admit, however, that they are a long way from having a general theory of social control.

\section{B. Theories of the Content of Norms}

A key shortcoming of the law-and-society school has been its failure to develop a theory of the content of norms. ${ }^{91}$ Why did the particular norms I found in Shasta County emerge? Why do basic norms such as honesty,

87 See Black, supra note 7; Lawrence M. Friedman, The Legal System: A Social Science Perspective 68-69 (1975); Robert L. Kidder, Connecting Law and Society: An Introduction to Research and Theory (1983); and Richard Lempert \& Joseph Sanders, An Invitation to Law and Social Science: Desert, Disputes, and Distribution (1986).

88 Black, supra note 7. Black has focused his work on the content of what I call controllerselecting rules. He has been less interested in the content of substantive, remedial, procedural, and constitutive rules.

89 See Griffiths, supra notes 5, 37; William L. F. Felstiner, The Logic of Mediation, in Black ed., supra note 5, at 251; see also William L. F. Felstiner, Richard L. Abel, \& Austin Sarat, The Emergence and Transformation of Disputes: Naming, Blaming, Claiming . . ., 15 Law \& Soc'y Rev. 631 (1980-81).

${ }^{90}$ Macaulay, supra note 51 ; Ian R. Macneil, The Many Futures of Contracts, 47 S. Cal. L. Rev. 691 (1974). The subsequent law-and-economics literature on self-enforced contracts (see note 39 supra) shows how transaction-cost economics can sharpen law-and-society insights.

91 See, for example, Homans, supra note 8, at 2 (in his major theoretical work, an eminent sociologist explicitly disclaims interest in content of norms); and Scott, supra note 11, at 9 (noting the tendency of sociologists to treat norms as independent variables). The most impressive recent theoretical work on the content of norms is Edna Ullmann-Margalit, The Emergence of Norms (1977). Her inspirations were game theory and philosophy, not sociology. 
promise keeping, and reciprocity seem to emerge in most societies $?^{92}$ Perhaps because they do not agree on a theory of human nature, ${ }^{93}$ sociologists and other law-and-society scholars have tended to treat observed norms as exogenous, not as dependent variables whose contents are to be explained.

Before documenting the law-and-society scholars' relative disinterest in the content of norms, I briefly review three theories of the substance of informal rules. These three theories are all currently unfashionable with most sociologists.

\section{Functionalist Sociology and Anthropology}

A supposedly outmoded theory that nevertheless stubbornly refuses to die holds that the norms of a social group serve to promote the group's survival and prosperity. A crude version of this functionalist theory appeared a century ago in the work of the social Darwinists. ${ }^{94}$ The theory gained more academic respectability when less overtly political versions were espoused by social anthropologists Malinowski and RadcliffeBrown in the 1920 s and the $1930 \mathrm{~s}^{95}$ and by leading sociologists such as Merton and Parsons in the 1950s. ${ }^{96}$ The writings of Émile Durkheim and Eugen Ehrlich, two of the founders of the sociology of law, also exhibited pronounced functionalist tendencies. ${ }^{97}$

In the conclusion of this paper I will put forward a hypothesis that suggests that functionalists have been on the right track. ${ }^{98}$ There can be

92 Some ethnographers have reported finding cultures where honesty, for example, is not highly prized. See, for example, Myrdene Anderson, Cultural Concatenation of Deceit and Secrecy, in Deception: Perspectives on Human and Nonhuman Deceit 323 (Robert W. Mitchell and Nicholas S. Thompson eds. 1986) (the Saami of Lapland often spread misinformation and reward entertaining deceivers).

${ }^{93}$ Sociologists tend to reject as being too reductionist the rational-actor model that economists and their allies use. A succinct review of the criticisms of the rational-actor model is Jack Hirschliefer, The Expanding Domain of Economics, 76 Am. Econ. Rev. 53 (1985).

94 The social Darwinists have no sympathizers today. See Richard Hofstadter, Social Darwinism in American Thought (rev. ed. 1965); and Edward O. Wilson, On Human Nature 208 (1978).

95 See, for example, Bronislaw Malinowski, Crime and Custom in Savage Society (1926); and Alfred R. Radcliffe-Brown, Taboo (1939). Homans has distinguished between these two scholars' forms of functionalism. See note 99 infra.

96 Robert K. Merton, Social Theory and Social Structure 1-84 (rev. ed. 1957); Talcott Parsons, The Social System (1951). See also Thibaut \& Kelley, supra note 10, at 135-42 (1959).

97 See Durkheim, supra note 15, at 49-229 (on the function of the division of labor); and Eugen Ehrlich, Fundamental Principles of the Sociology of Law (W. Moll trans. 1936). Ehrlich believed that law is relatively unimportant and that social forces tend to produce the same norms in all human societies.

98 See text at note 114 infra. 
no doubt, however, that functionalists have tended to be guilty of at least three types of analytic errors. First, functionalist thinking is apt to be circular. The analyst conclusively assumes that the norms observed are functional and resorts to loose theories of group morale building to explain brutal puberty rites and other bizarre practices. To escape charges of ex post rationalization, a functionalist must be able to predict the social control practices that would be observed in an as-yet-unexamined setting.

Second, and relatedly, functionalist sociologists and anthropologists have rarely been rigorous about how one would judge whether a norm was functional for a group. Some social practices may be beneficial to some members of a group but harmful to others. When a society conscripts its young adults to fight its wars, they may resent being sacrificed for the benefit of noncombatants. Economists have faced a similar analytic hurdle because one of their central terms, "efficiency," is potentially as ambiguous as is "functionality." Economists have met this challenge by developing and debating a variety of definitions of efficiency, for example, the Pareto-superiority criterion, the Kaldor-Hicks criterion, and so on. Functionalists in the softer social sciences, by contrast, have been less likely to confront this ambiguity in their theory.

Third, and again relatedly, early functionalists had a tendency to consider a human group as a single organism whose "health" could be examined. ${ }^{99}$ It was then easy for them to surmise that Darwinian evolutionary processes would help to favor the survival of socially adaptive norms. In the following passage, libertarian philosopher Friedrich Hayek lapses into this sort of analysis.

It is not only in his knowledge, but also in his aims and values, that man is the creature of civilization: in the last resort, it is the relevance of these individual wishes to the perpetuation of the group or the species that will determine whether they will persist or change. It is, of course, a mistake to believe that we can draw conclusions about what our values ought to be simply because we realize that they are a product of evolution. But we cannot reasonably doubt that these values are created and altered by the same evolutionary forces that have produced our intelligence. All that we can know is that the ultimate decision about what is good or bad will be made not by individual human wisdom, but by the decline of the groups that have adhered to the "wrong" beliefs. ${ }^{100}$

\footnotetext{
99 Homans called this version "societal functionalism." He criticized this approach, which he associated with Radcliffe-Brown, for ignoring that social phenomena grow out of the behavior of individual actors. Homans was more approving of "individualistic functionalism," which takes the individual as the basic unit of analysis. He identified Malinowski as a member of the latter school. Homans, supra note 80, at 154-57. A good introduction to the academic debate over functionalism is System, Change, and Conflict (Nicholas J. Demerath \& Richard A. Peterson eds. 1967).

100 Friedrich A. Hayek, The Constitution of Liberty 36 (Phoenix ed. 1978).
} 
Before nonlibertarian scholars dismiss these thoughts, they should be aware that Lon Fuller and Thomas Schelling have harbored suspiciously functionalist sentiments. ${ }^{101}$

The difficulty with this sort of organic analysis is that evolutionary processes, as most biologists understand them, select either genes or individual organisms, not groups, for survival. ${ }^{102}$ Assume, for example, that honesty is a functional norm in the sense that, if all the members of a group were consistently honest, they would each be better off than if each were consistently dishonest. Would the Darwinian struggle favor the survival of groups of honest persons? Not necessarily. A dishonest person living in an environment of honest people might especially prosper on account of being surrounded by easy marks. The Darwinian process would then tend to select dishonest people for survival. In short, to support a Panglossian scenario of group evolutionary progress, functionalists could not rely simply on the biological theory of natural selection. They instead had to develop theories to explain how social control systems would evolve within groups to prevent successful invasions by deviants who would subvert group welfare. The early functionalists never came close to filling in this missing theoretical link.

\section{Interest-Group Theories of Norms}

A second sociological theory, one less upbeat than functionalism, holds that members of powerful interest groups manipulate the content of norms to serve their own selfish interests. Traditional Marxist analysts, for example, see much of the normative baggage of a society as part of the false consciousness that deludes and hence pacifies the underclasses. Some neo-Marxist scholars, such as Isaac Balbus, and non-Marxist scholars, such as Howard Becker, also seem to have interest-group conceptions of norms. ${ }^{103}$ In the eyes of interest-group theorists, the traditional use in English of male pronouns to describe hypothetical persons might be seen as evidence of men's efforts to subjugate women. Rational-actor theorists, by contrast, might view this same usage as a normatively neutral linguistic convention that solves, as well as does any other, what game theorists call a game of pure coordination. ${ }^{104}$

101 See Fuller, supra note 37; T. Schelling, supra note 10, at 124-33.

102 See, for example, Richard Dawkins, The Selfish Gene 8-12 (1976); Edward O. Wilson, Sociobiology 106-29 (1975).

${ }^{103}$ See Isaac D. Balbus, Commodity Form and Legal Form: An Essay on the "Relative Autonomy" of Law, 11 Law \& Soc'y Rev. 571 (1976); Howard S. Becker, Outsiders 15-18, 147-63 (1963).

104 These games are analyzed in Thomas C. Schelling, The Strategy of Conflict 89-99 (1960); and in Ullmann-Margarlit, supra note 91, at 74-133. 
Interest-group theorists would win more converts if they could identify the mechanisms through which well-placed interest groups might manipulate the norm-making process. One can readily understand how concentrated lobbies might be able to influence the legal system. The informal control system, by contrast, is much more diffuse, and norms seem stubbornly resistant to deliberate influence. Totalitarian Communist regimes have not been able to produce a "new man," Madison Avenue cannot convince most motorists to buckle their seatbelts, and the right-to-life movement seems to have had little success in stemming the incidence of abortion. None of the various interest-group theories have yet offered a plausible explanation of how interest groups control the content of norms.

A second shortcoming of the various interest-group theories is that they are seriously incomplete. Many fundamental social norms appear neutral in content. It is hard to see how common norms of honesty, reciprocity, promise keeping, and respect for the bodily integrity of others serve the interests of the strong at the expense of the weak. Some norms, such as norms of charity, facially help people who lack power. Interest-group analysts must amplify their theories so as to be able to explain distributively neutral and progressive norms.

\section{Theories That Some Norms Are Genetically Hard Wired}

Over the past decade a handful of scholars, located mostly if not entirely outside sociology, have explored the possibility that certain core substantive norms are hard wired in the genetic material that humans carry. ${ }^{105}$ The emergence of sociobiology-a discipline that seeks to reconcile the widespread phenomenon of cooperation among animals with the Darwinian theory of evolution-has helped to stimulate this line of inquiry. ${ }^{106}$ As the theorists of hard-wired norms readily admit, their work to this point has been highly speculative.

A provocative article by Paul Rubin illustrates this type of scholarship. ${ }^{107}$ Rubin hypothesized that evolutionary processes shape human ethics and that tribes of hunter-gatherers had genetically influenced norms that were adapted to their situation. The rapid transition to modern mass society, Rubin speculated, has been too sudden for natural selection pro-

105 See George Edwin Pugh, The Biological Origin of Human Values (1977). See also Charles J. Lumsden \& Edward O. Wilson, Promethean Fire: Reflections on the Origin of Mind (1983); and A. Schotter, The Economic Theory of Social Institutions 160-64 (1981).

106 Wilson, supra note 102, is the seminal work. For criticism of the approach, see, for example, Philip Kitcher, Vaulting Ambition: Sociobiology and the Quest for Human Nature (1985).

${ }^{107}$ Paul H. Rubin, Evolved Ethics and Efficient Ethics, 3 J. Econ. Behav. \& Org. 161 (1982) 
cesses to have updated the relevant genes. A hunter-gatherer tribe might be better off, for example, if it had a norm that required tribe members to provide aid to the sick and impoverished because, in those societies, undeserving shirkers could readily be detected. This same norm of charity, suggested Rubin, might nonadaptively persist in anonymous mass societies, where shirking is harder to detect. This sort of analysis has won few converts, in part because (like functionalism) it seems to assume that the evolutionary process selects survivors at the level of the group, not of the individual.

\section{The Usual Sociological Approach: Norms as Exogenous Givens}

Most law-and-society scholars shy away from all theories of the content of norms. For example, in his justly famous study of contractual relations among Wisconsin business firms, Stewart Macaulay identified two principal norms that governed interfirm behavior: (1) "one ought to produce a good product and stand behind it"; and (2) "commitments are to be honored in almost all situations." 108 Essentially viewing people as rational actors who try to maximize their net gains, ${ }^{109}$ Macaulay seemed to regard most of the behavior he observed as somehow adaptive. Yet Macaulay offered no explanation for the emergence of the particular norms he observed. Why had the business culture not generated norms of "caveat emptor" and "there is no such thing as a binding commitment"? Macaulay did not venture to say. He passed up his opportunity to offer a theory of the content of norms and communicated only the (important) message that controller-selecting norms can discourage actors from using the legal system.

Similarly, in his enormously readable book The Human Group, sociologist George Homans identified "a norm that is one of the world's commonest: if a man does a favor for you, you must do a roughly equivalent favor for him in return."110 Homans drew on William Foote Whyte's Street Corner Society ${ }^{111}$ to illustrate this norm of reciprocity. Whyte had studied the Norton Street Gang, a group of young men of Italian descent living in a Boston slum. The Nortons believed in mutual aid but also in keeping accounts square: "In bad times as in good, if you have a few extra dimes you are expected to give them to your friend when he asks for them. You give them to him because he is your friend; at the same time

108 Macaulay, supra note 51, at 63.

109 Id. at 66.

110 Homans, supra note 11 , at 284

111 William F. Whyte, Street Corner Society: The Social Structure of an Italian Slum (1943). 
the gift creates an obligation in him. He must help you when you need it, and the balance of favors must be roughly equal. The felt obligation is always present, and you will be rudely reminded of it if you fail to return a favor."112 Although Homans stands out among sociologists for his clearheadedness, in the The Human Group and his other writings he treats particular norms, even one of the worlds's most common, as exogenous facts of life.

As these examples show, just as microeconomists tend to take consumers' tastes as given and limit themselves to the study of market processes, so sociologists tend to work not on what norms are but on how norms are transmitted. ${ }^{113}$

\section{Conclusion}

Identification of the components of the overall system of social control exposes gaps in current law-and-economics and law-and-society theory. Economists are commendably interested in the content of legal rules but tend to exaggerate the influence of these rules. Sociologists, who have been more aware that social control springs from many sources, have lagged in developing theories of the content of rules.

In my forthcoming book that grows out of my work in Shasta County, I will immodestly attempt to build a bridge between the two schools. The book will offer and explore a positive hypothesis of the content of norms: that, in the absence of specific "social imperfections," the norms that govern the relationships among members of a group will tend to maximize the aggregate wealth of group members. (Examples of social imperfections are the lack of a prospect of a future relationship and poor information about how group members behaved in the past.) This hypothesis of wealth-maximizing norms crystallizes several older intellectual traditions. It picks up the central idea of functionalist sociology and anthropology. It is consistent with the law-and-society scholars' theme that a continuing relationship is apt to civilize individual behavior. It suggests the sagacity of Lon Fuller, Friedrich Hayek, and like scholars, who have kept alive the Burkean notion that decentralized social forces contribute importantly to social order. The book will review the Shasta County evidence

112 Homans, supra note 11 , at 160 .

113 At the atheoretical extreme in sociology is the interpretivist position (now arguably dominant among anthropologists) that a particular culture just is what it is and, therefore, that an analyst can do no better than to acquire a local knowledge of the symbolic meaning of cultural practices. See, for example, Geertz, supra note 80, at 3-54 (1973). See generally Leff, supra note 80; and Henry A. Walker \& Bernard B. Cohen, Scope Statements: Imperatives for Evaluating Theory, $50 \mathrm{Am}$. Soc. Rev. 288 (1985) (cleavage within sociology between scientists and interpretivists). 
from which $I$ induced this hypothesis and also investigate whether the hypothesis is deducible from the branch of game theory that deals with repeated games.

For some readers the hypothesis of wealth-maximizing norms will conjure up Richard Posner's controversial hypothesis that the common law evolves in a wealth-maximizing direction. ${ }^{114}$ Because the judicial system and nonhierarchical social forces may operate differently, however, the validity of one of these hypotheses is not dependent on the validity of the other.

Lest the hypothesis of wealth-maximizing norms be seen as a blanket normative endorsement of using norms as rules, three sobering caveats are immediately in order. First, wealth maximization is a goal with only limited normative appeal. Second, social imperfections are common. The hypothesis therefore does not predict that the norm-making process would lead to the evolution of wealth-maximizing norms in a transient social environment, such as a singles bar at O'Hare Airport. And third, as norms of racial segregation in the Jim Crow era in the South plausibly illustrate, norms that add to the wealth of one group's members may impoverish, to a greater extent, outsiders to the group.

The hypothesis of wealth-maximizing norms has many normative and positive implications. For example, if the substantive norms that arise under perfect social conditions are indeed wealth maximizing in content, then, when those conditions prevail, a utilitarian lawmaker would want the law to incorporate social norms. The hypothesis thus suggests a normative underpinning for the law's use of business custom to flesh out business contracts. It also suggests that controller-selecting norms tend to allocate disputes among controllers so as to minimize a social group's sum of administrative costs and opportunity costs arising from failures to achieve cooperative outcomes. Thus, if Shasta County ranchers use norms to resolve trespass disputes and use law to resolve water disputes, the hypothesis suggests that this division of social control labor is one that maximizes their aggregate wealth.

\footnotetext{
114 Posner concisely outlined his theory in Richard A. Posner, A Reply to Some Recent Criticisms of the Efficiency Theory of the Common Law, 9 Hofstra L. Rev. 775, 775-77 (1981). See also Richard A. Posner, Economic Analysis of Law (3d ed. 1986). I am unpersuaded by Posner's thesis, in part because many recent common-law decisions in the United States have an overtly redistributive cast.
} 
HeinOnline -- 16 J. Legal Stud. 1001987 